\title{
Is Knowledge Enough? — Realising the Benefits of Free Trade
}

\section{Linda Richardson}

arly policy makers, such as Henry Parkes, appear to have understood the
costs of Protection:

The working man ... can gain nothing and would suffer severely from Protection. It is a policy to cheapen his brain and muscle and to increase the price of his food supplies and every article of clothing or comfort for his humble household; a policy to depreciate the hard earned sovereign which his wife takes to market. (Parkes, 1892:456)

However, this was not sufficient to prevent Australia from adopting Protectionist trade policies following Federation. It took more than a century for the message, that protection imposes significant direct and indirect costs that can outweigh benefits generated, to be translated into policy practice in Australia. Although acceptance of Free Trade arguments was not consistently reflected in policy until the second half of the 1980 s, the turning point probably occurred in the mid-1960s with the publication of a measure of the subsidy equivalent of the existing tariff in the Report of the Committee of Economic Enquiry (1965). The Tariff Board (and its successors) can be credited with the wider public dissemination of the existence, and extent, of these costs. From 1968-69 they published, in each Annual Report, estimates of effective rates of protection to industries. The Productivity Commission continues to refine the measurement of the costs of protection and publish additional relevant research. The independent public inquiry and reporting process, strengthened with the change to the Industries Assistance Commission (IAC) in 1974, contributed substantially to, and can be seen as having been necessary for, the policy turn-around of the 1970s and 1980s. The recent increase in demands for interventionist policy highlights the likelihood that the policy debate is not finished and that continuous public debate and policy scrutiny is a necessary, though not always sufficient, counterfoil to the incentives created by the ability to generate income transfers through Protectionist policies.

Linda Richardson is a PhD scholar in Economics in the Research School of Social Sciences at The Australian National University. She was previously employed as an Associate Lecturer in Economics at ANU and as a Research Officer at the then Industries Assistance Commission. 


\section{At the Beginning - Before Federation}

The first 'Australian' import duty was levied in 1800 (Reitsma, 1960:1) and such duties have been levied ever since. The issue of the tariff as an instrument of protection policy arose about the middle of the nineteenth century. This issue has been debated, with varying degrees of intensity, ever since. Whilst 'Protectionists' have focused on the impact on employment and on the distribution of income, 'Free Traders' have emphasised the costs of distorting resource allocation and the implicit taxation of consumers and other industries.

In 1892 B. R. Wise, an active supporter of free trade in New South Wales (NSW) politics, advised:

It is certain that an error has been made by many Free Trade writers in approaching the question of Protection from the wrong side, and contemplating it in a different aspect from that which is regarded by Protectionists themselves. Most of these writers deal almost exclusively with the influence of Free Trade upon the production of wealth, while the Protectionists chiefly direct their attention to the influence of a fiscal policy upon the distribution of wealth. The consequence has been that the arguments and illustrations of Free Traders have failed to appeal, as effectively as they deserve, to the mass of Protectionist voters... where the electorates are controlled by working men, the voters wish to understand the influence of that policy (free trade) in raising wages.... It must be shown that Free Trade has also an effect in raising wages. (Wise, 1892:7-9)

The 'Free Traders' appeared to have been unable to capitalise on this advice resulting in Protectionist sentiments dominating actual tariff making for most of Australia's history.

Protectionists have tended to combine 'infant industry' arguments with the idea that protection enabled maintenance of a larger population at a standard of living that would not otherwise have been possible. Arguments relating to defence or self sufficiency and unfair competition have also been prominent at various times throughout the history of this debate.

The belief, promoted by Protectionists, that protection raised real wages, or allowed a larger workforce to be employed at a given real wage, played an important part in moulding public opinion and has been particularly influential at times of high unemployment. It has been persuasive in Australia where real wages tend to be more than usually rigid in the face of market pressures for their reduction. But protection is likely to have very little effect on employment in general - any employment gains generated in protected industries are likely to be offset by losses in less protected industries. Protection is more likely to be sought to maintain employment in certain industries or regions and tends to be 
used because, unlike direct subsidies or once-only adjustment assistance, it does not involve budgetary outlays (Anderson and Garnaut, 1987:30-2).

Although the public debate has been focused on stimulation of economic growth and the consequent effects on employment and the standard of living, in practice implementation of policy has often been dominated by its impact on the distribution of income. This can be seen by a survey of Australian tariff making.

The history of import duties in Australia dates back to 1800 when NSW's Governor Hunter ordered charges on those spirits that were permitted to be landed (Reitsma, 1960:1). From 1819 colonial tariff legislation was under the direct control of Great Britain though each colony was able to, and did, develop individual systems of tariffs (Reitsma, 1960:5). Initially these import duties were predominantly for revenue purposes.

The Australian Colonies Government Act 1850 laid the basis for responsible government in the colonies but left tariff legislation to the colonies themselves. Great Britain imposed three limitations on the colonies' power to legislate in this regard: there should be no preferential treatment; there should be no duties on supplies to the armed forces; and there should be no legislation inconsistent with imperial trade treaties (Reitsma, 1960:5).

Between 1850 and 1856 the various colonies framed their constitutions and legislated their tariffs. NSW, Victoria and Tasmania evolving simple revenue tariffs with specific duties on a limited list of goods and no ad valorem duties. South Australia framed a slightly more complicated tariff with specific duties on spirits and tobacco and a uniform 5 per cent ad valorem rate on other goods not on the free list (Reitsma, 1960:6).

As the result of the individual colonies being able to develop their own trade policies the second half of the 19th century saw the development of increasingly divergent policies in NSW and Victoria, the most important colonies from the point of view of both population and trade. Within this policy-making context major debates over trade policy occurred, particularly in the 1850 s and early 1860 s culminating in Victoria enacting a protective tariff in 1866 but with NSW opting to pursue 'free trade' using import duties for revenue purposes only. The other colonies had tariffs primarily designed for revenue and were neither as protectionist as Victoria nor as staunch supporters of free trade as NSW.

The Victorian Assembly passed the first protectionist tariff in 1866 (Reitsma, 1960:7). The protectionist line focused on an infant industry argument combined with the impact development of such industries would have on employment opportunities.

The typical infant industry argument is for temporary protection of a new industry until it becomes established. The basic rationale is that a country can become internationally competitive in a particular product once it has acquired the necessary skills to produce it but the skills can only be acquired by production, and such production will not be competitive during the learning 
stages. Initially losses will result so no private sector agent will initiate such production. This has been one of the most widely-accepted arguments for protection in developing countries. However, as Corden (1974:269) shows 'a protection argument requires not just learning, but in addition either capital market or information imperfection, or otherwise externalities'. The infant industry argument for protection can be seen as, at best, a second-best policy approach after such things as improvement of capital markets and specific subsidisation for labour training. After the 1960s the idea that protection might allow the establishment of a new industry that would contribute to economic growth was rarely taken seriously (Anderson and Garnaut, 1987:30).

Nonetheless such arguments, particularly when combined with the belief that the general atmosphere engendered by manufacturing is more conducive to economic growth than that surrounding primary industries so that growth can be accelerated by protecting new manufacturing industries, tends to have widespread appeal. These arguments have been persuasive in countries like Australia, which had a strong comparative advantage in primary rather than manufacturing industry. They were often used in times when there was optimism in Australia that growth would be high, such as from the 1860 s to the 1880 s and in the two decades following the Second World War (Anderson and Garnaut, 1987:29).

This was the case strongly promoted by David Syme, editor of The Age newspaper, and a relentless driving force behind Protectionism in colonial Victoria:

By the system of naked competition our manufacturers or mechanics are prevented from even making a beginning in the work of opening up new sources of industry amongst us. ...[A] ban is put upon the attempt at the very outset; and in a few short years hence, if this prearranged practice of national industrial abortion is continued amongst us, the people of Australia will be as utter strangers to all scientific skill and practical dexterity in the arts and manufactures of highly civilised nations. (Pratt, 1908:108)

As employment of Victoria's vastly increased population (the consequence of the 1850 s gold-rush) was arguably the colony's most pressing problem of the time, the notion that a protective tariff could help secure such employment was probably the major argument that achieved popular support for this stance. Once accepted no (colonial) Victorian Government deviated from the established policy of trade protection. By 1883 Victoria had a tariff imposing duties on imports averaging 25 per cent (Reitsma, 1960:7-9).

In contrast NSW, under the influence of the influential politician Henry Parkes, an ardent Free Trader, maintained a free trade stance through the remainder of the nineteenth century. Parkes argued against protection on the 
basis of both increasing input costs and increased cost of consumption. In 1855 he argued

as to the proposed tax on salt, he had been informed on good authority that the colony exported in 1854 no less than 180,000 raw hides, or $89562 \mathrm{cwt}$. Now in preparation of those hides $14 \mathrm{lbs}$. of salt were required to each, and thus it would be seen that a tax upon salt would actually be an export duty of $3 \mathrm{~d}$. per hide on our own produce. (Parkes, 1876:53)

and, in 1886:

But to talk about Protection benefiting the masses who had to earn their bread by the sweat of their brow, how could it benefit them? How could it benefit the farmer to have 6d. a bushel on imported wheat if taxes were imposed on every article his wife and children wore or he used on his farm? How could it benefit the tin miner or the coal miner to have a tax on every article they consumed? How could this Protection be for the benefit of the working classes of this country. (Parkes, 1892:446)

Several other factors may have contributed to the different policy outcome in NSW. First, the NSW's Government's heavier reliance on revenue from the sale of Crown lands and from land and income tax lessened the need for Customs revenue. Second, NSW's industries could exploit the natural advantages of coal and other raw materials. Finally, a tendency toward policy that kept down the cost of living and the cost of production for export probably influenced the Free Trade outcome (Reitsma, 1960:9-10).

\section{Nationwide Protection - Federation to 1920}

In the negotiations leading to Federation the question of Free Trade versus Protection again arose. Federation brought an Australian customs union with free trade between the States ensured by section 92 of the Constitution. The first Australia-wide tariff was introduced in Parliament on October 8, 1901 but this was enacted in 1902 without the protection issue being resolved. This tariff had to allow for the financial obligations of the Commonwealth to the States, which no longer received their own revenue from duties. Approximately 25 per cent, by value, of imports remained duty free. More than 40 per cent of the revenue was to be raised by duties on stimulants and narcotics (at an average rate of 155 per cent). The remainder of ad valorem duties were estimated to average 19 per cent and specific and mixed rates to average the equivalent of 31 per cent ad valorem (Reitsma, 1960:11). These rates were something like the protective 
Victorian rates (Pincus, 1995:58). This was a compromise tariff pleasing neither Free Traders nor Protectionists though conceding more to the latter. With regard to the overall objective of this tariff the Minister stated "The first condition is revenue, but protection, to existing industries at least, must accompany it' (Hansard, 8.10.1901:5699).

The debate was resolved by Alfred Deakin's policy of The New Protection that won Labour's support by supplying a direct link between tariff protection and wages. Although direct legislation making encouragement of certain industries contingent on the payment of fair and reasonable wages was effectively ruled invalid by the High Court, all parties in the Federal Parliament had reached agreement in favour of protection policy. In addition, Justice Higgins had put the principle of the New Protection into practice in the 1907 Harvester Judgement in the Arbitration Court - establishing the principle of a basic wage with margins for skill.

The 1908 (Lyne) Tariff, produced as the result of this cooperation of the Labour and Deakin groups, is considered to be the first truly protectionist Australian tariff. It included over 440 articles with rates nearly double those fixed in 1902 and provided for a measure of discrimination in favour of British exports to Australia by way of preferential rates of tariff (Pincus, 1995:61). Thus by $1907 / 8$ protectionist arguments had dominated and protection, delivered, mostly via the tariff, on an industry-by-industry basis and according to cost disability, became the established practice followed until the mid-1960s.

Protection of domestic industries remained a major objective of industry policy throughout the next 70 years. The main instrument used to deliver protection has been the tariff, but it has also been provided by import quotas (particularly during the First World War, the 1950s and the 1970s), embargoes and industry plans (particularly in the late 1980s). Nonetheless the Protection versus Free Trade debate and the question of whether the existing protection was delivering the expected benefits continued on and off throughout the period.

The First World War (1914-1918) saw the emergence of the Country Party and, although it might have been expected that they would take an antiprotectionist stance, their main efforts were in the direction of extending the principle of protection to primary products. After the War Australian trade policy became increasingly protectionist. Defence was prominent in the arguments for protection - much being made of the danger of isolation and the inability of getting industrial supplies should there be another war (Reitsma, 1960:21).

Defence-based arguments assert that some import-competing industries are desired not only for what they produce now but also for what they would be available to produce in the event of future reduction of imports due, for example, to war or embargo on some vital raw material. Producers can not charge a price for this 'externality' as consumers fail to take account of the full benefits to the nation of this industry so the industry remains too small. 
Protection is an intervention that could correct for this divergence between the social and private value of the output. A variation on this theme is that a country should use protection to achieve a more balanced economy and as such be more self-sufficient and less vulnerable to foreign shocks.

\section{Protection Increases - 1920s to 1950s}

There were substantial increases in the level of the tariff following both world wars and in the late 1920 s to the early 1930s. The 1921 (Greene) Tariff was strongly protective and there can be little doubt that protection as such was strongly supported. This tariff was aimed at protecting industries that had emerged during the war, encouraging others that were desirable and diversifying and extending existing industries (Reitsma, 1965:21-2). The average tariff rate of the Greene Tariff was twice that of the Lyne Tariff of 1908. Further, there was an extension of the protectionist umbrella to shelter the new chemical, engineering, transport and electrical industries that had flourished during the war (Pincus, 1995:63). This was an era of 'Protection All Round': tariff-supported arbitration for wage earners, tariff protection for manufacturers and tariffsupported marketing schemes for rural industry (Pincus, 1995:64). The Tariff Board was established in 1921 to advise the government on tariff policy.

While the principles of protection were largely accepted over this period disquiet did arise several times and with it renewal of the Protection versus Free Trade debate. For example, there is evidence of the Tariff Board's increasing concern in the mid-1920s. Its 1925-26 Annual Report warned against the possibility of a wage-tariff spiral. This warning was reiterated and strengthened in their next Annual Report. The Government's response was, in 1927, to establish a committee, led by Brigden, to undertake an independent inquiry into the economic effects of the Australian tariff. The subsequent Report (Brigden et al, 1929) concluded that 'the advantage of protection is in the maintenance of a larger population than could have been expected at the same standard of living without the protective tariff' (p.140). However, the committee also warned that the strategy of using the tariff for protection could have reached its limit:

the policy of protection has not had very great net effects upon the prosperity of the community as a whole. It has not brought all the benefits expected nor has it been disastrous.... As the tariff grows, the costs overtake the benefits, because the benefits have natural limits while the costs have not. (p.6)

the total burden of the tariff has probably reached the economic limits, and an increase in this burden might threaten the standard of living. It is important, therefore, that no further increases in, or extensions of, 
the tariff should be made without the most rigorous scrutiny of the costs involved. (pp.6-7)

the excess costs of protection are as much as the richness of our resources justify, and probably somewhat in excess of that limit. (p.143)

and

we can only conclude that the present costs of protection are dangerously high. (p.144)

The warnings expressed in the Brigden Report were overshadowed by the onset of the Depression in 1929. Tariff levels increased substantially from 1929 through the early 1930s. Faced with external payments difficulties and unemployment, emergency tariffs were imposed by the Scullin Government in 1929 and repeatedly raised and extended. Various imports were prohibited, and a uniform tax ('primage' duty) levied on almost all imports. Although there were some tariff reductions in the late 1930s, in 1939 the average Australian tariff was still higher than before the Depression (Pincus, 1995:66-8).

During the Second World War new industries emerged and many existing industries greatly expanded. The level of protection provided by the existing tariff was sufficient for most industries in the immediate post-war period. However, in the period of post World War Two reconstruction Australian trade protection was broadened and escalated. Economic recovery in Europe and costs in Australia rising much faster than those of its main trading partners culminated in the introduction of temporary import controls and quotas in 1952. During the 1950s quantitative import restrictions temporarily supplanted tariffs, however the abolition of import licensing in 1960 reinstated the tariff as the dominant instrument of protection (Glezer, 1982:22). Through the 1940s, 1950s and 1960s Australian trade policy was focused on pursuing a strategy of import replacement and maintaining the various schemes to support the 'home' prices of agricultural exports even though it had signed the General Agreement on Tariffs and Trade (GATT) in 1947 (Pincus, 1995:69-70). Although the early 1960s was a period of trade liberalisation among advanced industrialised nations, Australia was one of the few to raise its protective barriers.

\section{Effecting A Change of Direction}

From the mid-1950s demands for assessment of the policy of protection became more insistent. In June 1958, the Associated Chambers of Commerce of Australia passed (for the third year in succession) a resolution requesting the 
government to conduct a full-scale tariff inquiry and the Tariff Board repeatedly recommended a Government sponsored tariff investigation (Reitsma, 1960:25).

Such demands eventually led to the establishment of the Vernon Committee in February 1963. Its report, Report of the Committee of Economic Enquiry (Vernon, 1965), provided the stimulus for policy re-examination. Whilst the central conclusion was that the costs of protection had not exceeded the benefits, it criticised the wide dispersion of rates of protection, particularly as measured by effective rates, and suggested that a benchmark rate be used. The Committee proposed that the contribution of the tariff would be greater if granted with more discrimination. It argued that existence of an industry cease to be sufficient grounds for protection, and suggested the adoption of a central benchmark by the Tariff Board based on development of the concept of 'economic and efficient'. This could be achieved by the adoption of a more intellectual framework on which to base tariff setting. The Committee also calculated a 'general cost disability' of Australian industry (less than 30 per cent) and a measure of the subsidy equivalent of the existing tariff (approximately $\$ 1$ billion or about 6 per cent of GDP in 1962, quoted from Glezer, 1982:89), and gave wider circulation to the concept of effective rates of protection.

These developments, combined with the appointment of G.A. Rattigan as chairman of the Tariff Board in May 1963, resulted in a complete reorientation of tariff making over the following decade. Rattigan was critical in focusing tariff policy making on its impact on resource allocation. As chairman, Rattigan became increasingly dissatisfied with the standard ad hoc and made-to-measure approach to tariff setting and with the extent of political interference from both the Department (Trade and Industry) and the Minister (McEwen).

In the latter half of the 1960s the Tariff Board began to look closely at the effects of tariff protection on resource allocation and to question the traditional approach to tariff making which essentially revolved around the review of duties only in response to manufacturers seeking increased assistance.

By 1967 Rattigan had arrived at a view of the Board as the Government's formulator of tariff policy. He realigned the intellectual foundations of that advice in favour of greater concern for resource allocation on an economy-wide basis - if the Board could not be systematic in its approach it was hampered in fulfilling its advisory functions. He proceeded to demolish the existing rules and to argue for a comprehensive standard for industry protection. The core of Rattigan's innovations, 'points of reference' in effective rate terms, became the framework for future tariff making (Glezer, 1982:92-3). 
The Tariff Board put into practice a more systematic approach to tariff making, including the development of criteria against which the desirability of encouraging different industries through the tariff could be judged (OECD, 1975:10). The Board achieved this by:

- applying broader criteria, especially taking into account the effects of protection on manufacturers other than those seeking protection;

- from 1968-69 on, measuring and publishing effective rates of protection (1968-69 estimates of the effective rate of assistance -36 per cent for the manufacturing sector - were the first in a series which has been maintained ever since (Industry Commission, 1991:16));

- expanding the Board's research capacity and improving its analysis; and

- in 1971 , commencing general tariff reviews to assess the overall impact of the tariff.

By so doing Rattigan and the Tariff Board began realigning the aim of the tariff in favour of providing appropriate incentives for efficient resource allocation and away from supporting domestic industry against import competition.

Over the next decade protection policy was increasingly questioned and more attention paid to the costs and benefits of this policy and, for the first time, costs were seen to outweigh the benefits. As a result there was a shift, in theory if not entirely in practice, toward lowering of protection. Protection levels since then have in general decreased but largely as the result of the significant reductions occurring, or announcement of schedules thereof, in 1973, 1988 and 1991.

In July 1973 the Whitlam Government cut tariffs by 25 per cent on all goods except those subject to excise duties (Industry Commission, 1995a:33). In 1974 the Tariff Board was replaced with the Industries Assistance Commission (IAC), a statutory authority, and its charter was extended to all sectors. Rattigan remained as its chairman.

From the mid-1970s Australia reduced some tariffs even further but it also increased its protection against imports of textiles, clothing, footwear (TCF) and passenger motor vehicles (PMV) substantially through quantitative import restrictions (Anderson and Garnaut, 1987:7). The downturn in economic conditions in 1974-75 saw considerable increases in requests for temporary assistance, much of which was granted in the form of quantitative import restrictions. TCF and PMV industries were the major recipients, but they were also applied to a number of other items including fabricated steel products, refrigerators and other household appliances. However quotas applying to these other items were quickly removed while those for TCF and PMV became a long-standing form of assistance. TCF quotas were not removed until March 1993 (Industry Commission, 1995a:96). PMV quotas were removed, following a mid-term review of the PMV plan, in April 1988 (Industry Commission, 
1991:6). Further reductions in duty rates, applying to some 900 tariff items, occurred in January 1977 following an IAC report on Multilateral Trade Negotiations (MTN). The changes were intended to minimise adverse effects on local industries and largely involved the removal of unused assistance from lightly-assisted, low-cost industries. (Industry Commission, 1995a:33-4).

Since the late 1980s Australia has unilaterally reduced its tariff protection for industry. Major changes to industry assistance for both the manufacturing and agricultural sectors were announced in May 1988 and March 1991.

The May 1988 Economic Statement announced a general program of phased reductions in maximum tariff rates for most imports. By July 1992 tariffs above 15 per cent (with some exceptions, such as PMV and TCF) and between 15 and 10 per cent had been phased down in five equal steps to 15 and 10 per cent respectively. In addition, the 2 per cent revenue duty on imports was removed (Industry Commission, 1995a:34). When fully implemented, the May 1988 program is estimated to reduce the average tariff on imports entering Australia from just under 7 per cent in 1989-90 to 5.5 per cent (Industry Commission, 1991:1).

Assistance to the Australian manufacturing sector continued to decline under the program of reductions set in place by the Commonwealth Government in 1991. The March 1991 Statement changes were projected to reduce the average tariff further to about 2 per cent (Industry Commission, 1991:1). For the manufacturing sector, the March 1991 Statement changes were to reduce the standard deviation (a statistical measure of deviation) for both nominal and effective rates by more than half, relative to the end of the May 1988 program (Industry Commission, 1991:2). The general program of phased tariff reductions, begun in March 1991, was completed in July 1996 with all tariff rates except those protecting the PMV and TCF industries falling to 5 per cent or less (Productivity Commission, 1998:52). The PMV and TCF industries were scheduled to have tariffs of 15 and up to 25 per cent, respectively, in 200001 (Industry Commission, 1995b:18-9). The PMV and TCF industries have, and will continue to have, rates of assistance several times higher than all other manufacturing industries (Productivity Commission, 1998:XI).

With the conclusion of the Uruguay Round of GATT and the APEC Bogor Declaration of November 1994 Australia made further substantial commitments to freer trade.

In 1997 the Government considered post-2000 arrangements for the motor vehicle industry and for textiles, clothing and footwear. By now there was far greater public appreciation of the general impact of tariffs than ever before:

The tariffs on cars and clothing directly raise the price of these products by 8 and 7 per cent respectively. ... But the indirect effects are even more dramatic. Tariffs on cars, textiles and clothing increase the price of other household items by an average 2 per cent. So if car, 
textile and clothing tariffs were removed every household would have an extra $\$ 22.60$ to spend every week. (Pearce and Stoeckel, 1996:17)

Those who benefit from protection fought for its continuation and at least some policy makers remained reluctant to treat these industries in the same way as the rest. Arguments were made that protection should only be reduced where major trading partners cut their protection and after labour market and other microeconomic reforms.

In the event the Government decided to maintain the PMV tariff at 15 per cent from 2000 until January 2005 , when it is scheduled to fall to 10 per cent. Assuming no other changes in assistance the effect of this pause will be to maintain effective assistance to PMV at 19 per cent, nearly 4 times the manufacturing average. Similarly, in 2000 all TCF imports (apart from those already at 5 per cent or less) will be subject to tariff rates of either 25,15 or 10 per cent. They will remain at these levels until 2005, when tariffs on apparel and certain finished textiles, footwear and fabrics are scheduled to decline to $17.5,10$ and 7.5 per cent respectively. The effective rate for the clothing and footwear industries is projected to fall to 34 per cent by 2000-01 (Productivity Commission, 1998:54), much higher than the projected manufacturing industry average of 5 per cent.

In addition, the government announced the removal of tariffs on business inputs in information technology, telecommunications and medical and scientific equipment. While this will not have much impact on assistance to manufacturing in general (at the 2-digit subdivision level) this decision will increase effective assistance for industries using these inputs (Productivity Commission, 1998:55).

\section{Is the Debate Resolved?}

Since the 1970s policy makers, and others, appear to have been increasingly convinced that import protection was not delivering the expected benefits, or to the extent it was, the costs of that protection outweighed the benefits. By the late $1980 \mathrm{~s}$ a commitment to trade liberalisation was consistently reflected in policy. Free Traders appeared to have finally won with an emerging consensus that past protection damaged Australia and resulted in a legacy of inwardlooking and uncompetitive manufacturing (Smith, 1995:479). The general trend of policy development appeared to be as described by Freedman and Stonecash (1997:181) that 'the role of government is to set the competitive environment and then get out of the way. The idea of directing resources to specific sectors through policy has been abandoned'.

Banks (1998) argues a major factor contributing to this progress has been the increased capacity of policy making processes to take an economy-wide view on industry assistance issues. This has been achieved by: 
an approach to policy formulation that has some uniquely Australian characteristics. By and large the debate is relatively well informed and open, and the policy-making process is ultimately disciplined by a high degree of public scrutiny. (p.147)

Although the debate over tariff protection appeared to be over by the late $1980 \mathrm{~s}$, in the 1990s there has been a resurgence of protectionist arguments (Banks, 1998:147); particularly based on unfair competition and nationalism, which have been accompanied by demands for strategic trade policy to create export winners. The arguments used are often no different from those that have been used in support of protection throughout Australia's history.

The situation today is, as it has always been, and is neatly summarised by Rattigan (1986:273):

Because Governments will always be exposed to strong pressures from sectional interests, continuous informed public discussion and adequate public scrutiny of the policy-making process are necessary as safeguards for promoting fair and open dealing. This is especially true in a section of government administration such as assistance to industry, where there is great scope for deals to be made between Ministers and sectional interests which confer considerable political benefits on the former and considerable financial benefits on the latter all at the expense of the community as a whole.

Relatively well-informed and open debate has, and should continue, to play a role in the tariff setting process but recent history indicates it will not always be sufficient to maintain the momentum for trade liberalisation. In Australia such debate has certainly increased the political cost of providing protection to industry. However, wherever the perceived political benefits of assisting particular industries continue to outweigh such costs the incentive remains for politicians to maintain or even increase protection to those industries.

\section{References}

Anderson, K. \& R. Garnaut (1987), Australian Protectionism: Extent, Causes and Effects, Allen \& Unwin, Sydney.

Banks, G. (1998), 'Committing to Trade Liberalisation in Australia', Agenda 5(2):147-64.

Brigden, J. B. et al (1929), The Australian Tariff: An Economic Enquiry, Melbourne University Press, Melbourne.

Corden, W.M. (1974), Trade Policy and Economic Welfare, Clarendon Press, Oxford.

Freedman, C. \& R. Stonecash (1997), 'A Survey of Manufacturing Industry Policy: From the Tariff Board to the Productivity Commission', The Economic Record 73(221):169-83. 
Glezer, L. (1982), Tariff Politics: Australian Policy Making 1960-1980, Melbourne University Press, Melbourne.

Industry Commission (1991), Changes to Manufacturing Industry Assistance March 1991, AGPS, Canberra.

Industry Commission (1995a), Assistance to Agriculture and Manufacturing Industries, AGPS, Canberra.

Industry Commission (1995b), Annual Report 1994-95, AGPS, Canberra.

OECD (1975), The Industrial Policy of Australia, Organisation for Economic Cooperation and Development, Paris.

Parkes, H. (1876), Speeches on Various Occasions Connected with the Public Affairs of N.S.W.: 1848-1874, George Robertson, Melbourne.

Parkes, H. (1892), Fifty Years in the Making of Australian History, Longman Green, London.

Pearce, D. \& A. Stoeckel (1996), 'One Shoe Per Person': Explaining the Hidden Trade-offs in Protection Policy, Centre for International Economics, Canberra.

Pincus, J. (1995), 'Evolution and Political Economy of Australian Trade Policies', Ch. 2 in R. Pomfret (ed.), Australia's Trade Policies, Oxford University Press, Melbourne.

Pratt, A. (1908), David Syme: The Father of Protection in Australia, Ward Lock \& Co Ltd, Melbourne.

Productivity Commission (1998), Trade \& Assistance Review 1997-98, Annual Report Series 199798, Ausinfo, Canberra.

Rattigan, G.A. (1986), Industry Assistance: the Inside Story, Melbourne University Press, Melbourne.

Reitsma, A. J. (1960), Trade Protection in Australia, University of Queensland Press, Brisbane.

Smith, H. (1995), 'Beyond Picking Winners? Recent Writings on Australia's Industry Policy', Agenda 2(4):479-88.

Vernon, J. (1965), Report of the Committee of Economic Enquiry, Wilke \& Co. Lid., Melbourn.

Wise, B.R. (1892), Industrial Freedom: A Study in Politics, Cassell \& Co, London.

I am grateful to Robert Albon, Chris Lee and two anonymous referees for comments on an earlier draft. The usual disclaimer applies. 